\title{
Co-digestion of Laminaria digitata with cattle manure: A unimodel simulation study of both batch and continuous experiments
}

Sun, Hao; Kovalovszki, Adam; Tsapekos, Panagiotis; Alvarado-Morales, Merlin; Rudatis, Amata; Wu, Shubiao; Dong, Renjie; Kougias, Panagiotis ; Angelidaki, Irini

\section{Published in:}

Bioresource Technology

Link to article, DOI:

10.1016/j.biortech.2018.12.110

Publication date:

2019

Document Version

Peer reviewed version

Link back to DTU Orbit

Citation (APA):

Sun, H., Kovalovszki, A., Tsapekos, P., Alvarado-Morales, M., Rudatis, A., Wu, S., Dong, R., Kougias, P., \& Angelidaki, I. (2019). Co-digestion of Laminaria digitata with cattle manure: A unimodel simulation study of both batch and continuous experiments. Bioresource Technology, 276, 361-368.

https://doi.org/10.1016/j.biortech.2018.12.110

\section{General rights}

Copyright and moral rights for the publications made accessible in the public portal are retained by the authors and/or other copyright owners and it is a condition of accessing publications that users recognise and abide by the legal requirements associated with these rights.

- Users may download and print one copy of any publication from the public portal for the purpose of private study or research.

- You may not further distribute the material or use it for any profit-making activity or commercial gain

- You may freely distribute the URL identifying the publication in the public portal 


\section{Accepted Manuscript}

Co-digestion of Laminaria digitata with cattle manure: a unimodel simulation study of both batch and continuous experiments

Hao Sun, Adam Kovalovszki, Panagiotis Tsapekos, Merlin Alvarado-Morales, Amata Rudatis, Shubiao Wu, Renjie Dong, Panagiotis G. Kougias, Irini Angelidaki

PII:

DOI:

Reference:

To appear in:

Received Date:

Revised Date:

Accepted Date:
S0960-8524(18)31781-4

https://doi.org/10.1016/j.biortech.2018.12.110

BITE 20867

\section{Bioresource Technology}

29 October 2018

28 December 2018

29 December 2018



Please cite this article as: Sun, H., Kovalovszki, A., Tsapekos, P., Alvarado-Morales, M., Rudatis, A., Wu, S., Dong, R., Kougias, P.G., Angelidaki, I., Co-digestion of Laminaria digitata with cattle manure: a unimodel simulation study of both batch and continuous experiments, Bioresource Technology (2018), doi: https://doi.org/10.1016/ j.biortech.2018.12.110

This is a PDF file of an unedited manuscript that has been accepted for publication. As a service to our customers we are providing this early version of the manuscript. The manuscript will undergo copyediting, typesetting, and review of the resulting proof before it is published in its final form. Please note that during the production process errors may be discovered which could affect the content, and all legal disclaimers that apply to the journal pertain. 


\section{Co-digestion of Laminaria digitata with cattle manure: a unimodel}

\section{simulation study of both batch and continuous experiments}

Hao Sun ${ }^{\mathrm{a}, \mathrm{b}}$, Adam Kovalovszki ${ }^{\mathrm{b}}$, Panagiotis Tsapekos ${ }^{\mathrm{b}}$, Merlin Alvarado-Morales ${ }^{\mathrm{b}}$, Amata Rudatis ${ }^{\mathrm{b}}$, Shubiao Wu ${ }^{\mathrm{a}, \mathrm{c}}$, Renjie Dong ${ }^{\mathrm{a}}$, Panagiotis G. Kougias ${ }^{\mathrm{b}, \mathrm{d} *}$, Irini Angelidaki ${ }^{\mathrm{b}}$

${ }^{a}$ College of Engineering, China Agricultural University, Key Laboratory for Clean Renewable Energy Utilization Technology, Ministry of Agriculture, Beijing 100083, PR China

${ }^{\mathrm{b}}$ Department of Environmental Engineering, Building 113, Technical University of Denmark, DK-2800 Lyngby, Denmark

${ }^{c}$ Aarhus Institute of Advanced Studies, Aarhus University, Høegh-Guldbergs Gade 6B, DK-8000 Aarhus C, Denmark

${ }^{\mathrm{d}}$ Institute of Animal Sciences, Hellenic Agricultural Organisation DEMETER, GR-58100 Paralimni, Greece

*Corresponding author

Dr. Panagiotis G. Kougias

E-mail address: panak@env.dtu.dk, Tel: +45 45251454, Fax: +45 45932850 


\section{Abstract}

This work investigated the thermophilic $\left(55^{\circ} \mathrm{C}\right)$ co-digestion performance both in batch and continuous mode operation. The biochemical methane potentials of L. digitata and cattle manure were $308 \pm 24$ and $203 \pm 33 \mathrm{~mL} \mathrm{CH}_{4} / \mathrm{g} \mathrm{VS}$, respectively. The optimum co-digestion feedstock ratio was found to be $80 \%$ macroalgae: $20 \%$ manure on a volatile solids basis, which produced $290 \pm 19$ $\mathrm{mL} \mathrm{CH}_{4} / \mathrm{g}$ VS under long-term and stable continuous operation at an organic loading rate of $2 \mathrm{~g}$ VS/L/d and hydraulic retention time of 15 days. Simulations of the batch and continuous experiments were, for the first time, carried out using an integrated anaerobic bioconversion model without structural modifications. Close fits between measured and simulated data provided mutual confirmation of experimental reliability and model robustness, and provided new perspectives for the use of the software tool.

Keywords: Macroalgae; Laminaria digitata; cattle manure; co-digestion; modeling 


\section{Introduction}

A transition of energy resources from fossil fuel to renewables is mandatory to combat world climate change and build a sustainable society (Bentsen and Møller, 2017). The European Union has set an ambitious target by 2030 of increasing to at least $27 \%$ share of the renewable energy consumption and reducing the $\mathrm{CO}_{2}$ emissions by at least $40 \%$ compared to the 1990 levels to achieve a more competitive and sustainable energy system (European-Council,2014). Interest in exploiting renewable energy sources in order to accelerate the independence from fossil fuels and mitigate $\mathrm{CO}_{2}$ emissions are increasing in recent years (Scarlat et al., 2015). Thus, production of biofuels from various types of biomasses has attracted worldwide interest (Ellabban et al., 2014).

The increasing production of first-generation bioenergy, mainly using energy crops, is limited due to concerns of the competition of energy or food generation (Naik et al., 2010). While traditionally used substrates, such as agricultural residues and livestock slurries, are preferred for the second-generation bioenergy production, they are still facing several technical barriers which are associated with their efficient utilization (Guneratnam et al., 2017; Mohr and Raman, 2013). Highly productive marine biomass, such as macroalgae, is regarded as a suitable feedstock for biofuel production and has been considered as third generation biofuel (Behera et al., 2015). Production of such biofuels can avoid land occupation, thus not competing with the growth of food-based crops. Additionally, a large amount of beach-cast seaweed annually rots and smothers the coastlines, resulting in a negative environmental impact (Smetacek and Zingone, 2013). The exploitation of such residues as feedstock in anaerobic digesters can counteract the adverse effects from the rotten seaweed (smell and flies), and simultaneously can generate a renewable bioenergy.

Macroalgae are known to be rich in carbohydrates and contain soft lignocellulosic materials, which 
are easily fermented with high conversion efficiencies (Seghetta et al., 2017). However, long-term mono-digestion of macroalgae could be problematic, potentially due to the accumulation of volatile fatty acids (VFAs), lack of buffer capacity, or salt inhibition (Sarker et al., 2014). Co-digestion of macroalgae with livestock manure contributes in overcoming several operational challenges as aforementioned (Montingelli et al., 2015), and finally increase the methane production compared to the mono-digestion of macroalgae. Overall, such co-digestion strategy can turn macroalgae into a viable substrate, while supplying biogas plants with an energy-dense organic waste and providing them with operational and financial benefits (Nielsen and Heiske, 2011).

Among different species of macroalgae, Laminaria digitata is proved to be a good candidate for anaerobic digestion (AD) trials, since its $\mathrm{C} / \mathrm{N}$ ratio was reported to exceed 20 when harvested in late summer or autumn (Ganesh Saratale et al., 2018; Tabassum et al., 2016). It is mostly found in Nordic coastal areas and has a high intrinsic growth rate $(1.3 \mathrm{~cm} /$ day on average during the season of maximal growth) (Sarker et al., 2014). Its biochemical methane potential (BMP) ranged between 93-394 mL/g VS, largely depending on the variation of its composition (Adams et al., 2011; D'Este et al., 2017). Continuous mesophilic co-digestion of L. digitata and cattle manure (algae share: $15-41 \%$ on VS basis) did not augment the methane production, possibly due to inefficient hydrolysis (Sarker et al., 2014). However, the methane productivity was found to be increased by approximately $40 \%$ during thermophilic co-digestion (algae share of $24 \%$ on VS basis) compared to mono-digestion of cattle manure. A further increment of the algae share to $41 \%$ could only enhance the methane production by $13 \%$, potentially as a result of the system inhibition (VFAs accumulation) given the further increase in algae feeding (Sarker et al., 2014). Up to date, there is still lack of systematic investigation during the co-digestion performance of L. digitata with cattle manure. The effect of feedstock mixing ratios and the stability of the process under long-term continuous reactor operation are essential challenges that should be well-addressed before practical applications. 
Mathematical modeling is a tool that can assist research to efficiently optimize processes, or predict output in several conditions. In the last few decades, there has been a growing trend in using computational tools for the simulation of experimental AD processes, in order to cross-validate the reliability of both experiments and models or to provide large-scale facilities with cost-effective tools for process planning, monitoring and forecasting (Batstone et al., 2015; Kythreotou et al., 2014). Furthermore, while laboratory experiments might be limited to a selected number of treatments due to constraints on time, labor, equipment and other resources, computer-aided AD models can generate simulation results from a multitude of experiments, on a much smaller time frame (Donoso-Bravo et al., 2011). Applying such tools for the evaluation of traditional experimental $\mathrm{AD}$ work should, therefore, form a significant part of $\mathrm{AD}$ research studies. However, combined verification of experimental data and model simulations in different biogas reactor systems (i.e. batch and continuous mode) was rarely reported, especially for co-digestion cases.

Considering the above, the methane production could be enhanced with the addition of $L$. digitata in feedstock and a stable long-term operation could be achieved following a co-digestion strategy under thermophilic conditions. Accurate simulations from mathematical models, such as the BioModel, which are validated by experimental data, constitutes the basis for the development of tools that will lead to process optimization. The present work provides a detailed analysis of the co-digestion of L. digitata with cattle manure to enhance biogas production. Mono- and co-digestion of both substrates under batch conditions were performed to determine the optimum mixing ratio. The continuous experiment was subsequently carried out using a continuously stirred tank reactor (CSTR) to further examine the performance of the co-digestion process. Finally, for the validation of the experimental results, a mathematical model (BioModel) was adapted to simulate both the batch and continuous experiments. 


\section{Material and methods}

\subsection{Inoculum, cattle manure and algae}

Thermophilic inoculum $\left(54 \pm 1^{\circ} \mathrm{C}\right)$ for BMP experiment was obtained from a laboratory scale anaerobic digester that treated cattle manure together with source separated organic fraction of municipal wastes (Tsapekos et al., 2018). Anaerobic inoculum for the continuous co-digestion experiment was collected from the thermophilic biogas plant, Snertinge biogas plant (Sealand, Denmark), in which livestock slurries and agricultural biomasses are co-digested. Prior to these tests, the inoculum was sieved to remove the large particles and then stored in a thermophilic incubator $\left(54 \pm 1^{\circ} \mathrm{C}\right)$. Raw cattle manure was obtained from Hash $\varnothing$ j biogas plant (Sealand, Denmark). After collection, the manure was sieved to remove large particles. Then, the treated manure was stored at $-20^{\circ} \mathrm{C}$ to prevent any alteration in its chemical composition. Prior utilization, cattle manure was thawed at $4^{\circ} \mathrm{C}$. L. digitata was chosen as the macroalgae biomass because of its carbohydrate-rich content compared to the other species that are abundant in Nordic littorals. In this study, L. digitata was collected from the Danish North Sea coast (north of Hanstholm-7730, Denmark) on August $30^{\text {th }}$ 2012. After arrival to the laboratory, the macroalgae were washed and stored in a freezer at $-20^{\circ} \mathrm{C}$. The algal biomass was physically pre-treated: first dried in an incubator at $55^{\circ} \mathrm{C}$ for several days until its moisture content was below $10 \%$; then, it was cut with a cutting mill (SM 200, Retsch GmbH, Germany) to reduce the particle size and sieved to obtain less than 4 $\mathrm{mm}$ in size. The chemical compositions of the raw substrates and the degassed inoculum are presented in Table 1 and Table 2.

\subsection{Batch assay and continuous reactor operation}

BMP assays based on the proposed protocol (Angelidaki et al., 2009) were conducted to determine 
the bioenergy production of the L. digitata and cattle manure under mono- and co-digestion trials and examine the optimum co-digestion mixing ratio. In the sample-containing batches, six ratios of macroalgae to manure were tested defined as 100:0, 80:20, 60:40, 40:60, 20:80 and 0:100 in terms of VS. The total and working volume of each batch vial were 547 and $150 \mathrm{~mL}$, respectively. Each bottle contained $120 \mathrm{~mL}$ inoculum. The remaining $30 \mathrm{~mL}$ were filled with substrates and water. The initial organic load for all the batch treatments was $2 \mathrm{~g} \mathrm{VS} / \mathrm{L}$ (except for the blank). Prior to thermophilic incubation $\left(54 \pm 1^{\circ} \mathrm{C}\right)$, the batch vials were flushed with pure nitrogen, closed tightly with a rubber stopper and sealed with aluminum crimp to ensure anaerobic conditions. During the incubation period, the vials were manually shaken and the methane content was measured twice per week. The assays lasted for 21 days, until methane production ceased $(\mathrm{p}<0.05)$.

The co-digestion process performance of $L$. digitata with cattle manure was also examined under continuous operation mode with a CSTR (total and working volume: 9.0 and $7.5 \mathrm{~L}$, respectively). The mixed substrates were diluted with deionized water to reach an organic loading rate of $2 \mathrm{~g}$ VS/L/d in the reactor. The reactor was heated by a silicone thermal jacket to maintain the temperature at $54 \pm 1^{\circ} \mathrm{C}$. Continuously and gently magnetic stirring was adopted to achieve homogenous mixing of the biogas slurry. The hydraulic retention time (HRT) was kept at 15 days. Daily biogas production was monitored via an automated gas metering system (Angelidaki et al., 1992). Biogas and liquid samples were taken from the reactor every three days to determine the methane content, $\mathrm{pH}$ and VFAs concentration.

\subsection{Analytical methods}

The concentrations of total solids (TS) and volatile solids (VS), chemical oxygen demand (COD), total ammonium nitrogen $\left(\mathrm{NH}_{4}^{+}\right)(\mathrm{TAN})$, total Kjeldahl nitrogen (TKN) and carbohydrates contents were determined by following the standard methods (APHA, 2005). The $\mathrm{pH}$ was determined after 
sampling with a digital $\mathrm{pH}$ meter (Radiometer PHM 92, USA). The methane content was measured by a gas chromatograph (GC) (Thermo Scientific, TRACE 1310) equipped with a flame ionization detector (FID). VFAs were quantified by using the GC (Thermo Scientific, TRACE 1300) with FID in duplicates (Khoshnevisan et al., 2018). The hydrogen sulfide $\left(\mathrm{H}_{2} \mathrm{~S}\right)$ was measured with a gas analyzer (Geotech Biogas 5000, Germany). The metal analysis was performed using inductively coupled plasma with optical emission spectrometry (ICP OES).

\subsection{Modeling and simulation of the process}

The computational evaluation of the anaerobic conversion of cattle manure and L. digitata under batch conditions and in a continuously fed digester was performed by applying a dynamic bioconversion model (BioModel) proposed by Angelidaki et al. (1993, 1999) and a hybrid MATLAB-Microsoft Excel software environment. Model parameters optimized for the simulation of mono- and co-digestion scenarios were taken from Kovalovszki et al. (2017) in a manner similar to Tsapekos et al. (2018), while gas-liquid equilibrium calculations were based on an earlier work of Lovato et al. (2017). Further to that, the simulation output format of the model was extended, allowing the production of cumulative gas volume data for batch simulations, in addition to the volumetric gas flow rates already generated during the simulation of continuous experiments. The simulation procedure followed a systematic, three-step process: (1) simulation of all treatments of the batch experiment and calibration of the BioModel, in order to find suitable inoculum fractionation and hydrolysis constants $\left(k_{0}\right)$ that produce batch simulations with high accuracy; (2) calibration of the BioModel for the simulation of the continuous experiment, using process data from the first three HRTs of the experiment and the hydrolysis constant that in the previous step was found most suitable for the hereby applied substrate mixing ratio; (3) simulation of the whole duration of the continuous experiment to validate the reliability of the BioModel in forecasting the 
long-term behavior of the process.

\subsection{Statistical analysis}

Tukey's post hoc test $(\mathrm{p}<0.05)$ was carried out to determine the statistically significant differences among mono- and co-digestion samples with the OriginPro 9.0.0 SR2 software (OriginLab Corporation, USA). The prediction accuracy of the regression model was assessed with the coefficient of determination $\left(\mathrm{R}^{2}\right)$ and root mean square error (RMSE).

\section{Results and discussion}

\subsection{Batch assays with $L$. digitata and cattle manure}

Batch assays were conducted to obtain the maximum methane yield of $L$. digitata and cattle manure, as well as the most efficient co-digestion ratio between two substrates. The methane yield obtained from mono-digestion of $L$. digitata was $308 \pm 24 \mathrm{~mL} / \mathrm{g}$ VS, which was in agreement with the findings $(310 \pm 9 \mathrm{~mL} / \mathrm{g}$ VS) of a previous test using $L$. digitata harvested from the same area and similar period (D'Este et al., 2017). The theoretical methane potential (TMP) of L. digitata in this study was $411 \mathrm{mLCH}_{4} / \mathrm{g}$ VS, estimated based on COD contents $\left(350 \mathrm{mLCH}_{4} / \mathrm{g} \mathrm{COD}\right)$. The biodegradability of used macroalgae reached $75 \%$ and was comparable to the findings of a previous study (74\%) (D'Este et al., 2017). Moreover, literature values for L. digitata TMP varies between 215 and 479 mL/g VS, while the BMP ranges between 93-394 mL/g VS (Adams et al., 2011; Allen et al., 2015; D'Este et al., 2017; Edward et al., 2015; Membere and Sallis, 2018; Tabassum et al., 2016). The biodegradability (BMP/TMP) of thermophilic fermentation L. digitata ranged from 52 to $96 \%$ (D'Este et al., 2017; Membere and Sallis, 2018). The main reason for these variations is the biomass composition of $L$. digitata, which can vary remarkably during different harvesting seasons 
and geographical locations (D'Este et al., 2017; Tedesco and Daniels, 2018).

The methane yield of cattle manure was $203 \pm 33 \mathrm{~mL} / \mathrm{g}$ VS (Fig. 1), which is in line with previous findings demonstrating the poor biomethanation potential of livestock residues $(181 \pm 6 \mathrm{~mL} / \mathrm{g}$ VS) (Tsapekos et al., 2018). Cattle manure usually contains a high amount of inorganic compounds and fibers (mainly composed of lignin molecules), thus causing limited biodegradability and further lowering the methane productivity (Nasir et al., 2012). The methane yield of cattle manure was significantly lower than that of L. digitata $(\mathrm{p}<0.05)$. The biodegradability of mono-digestion of cattle manure (54\%, TMP: $338 \mathrm{mLCH}_{4} / \mathrm{g}$ VS) was also inferior to that of L. digitata. This can be explained by the fact that L. digitata is a substrate with high carbohydrates content (Glucose: $39.5 \pm 0.1 \%$ TS, Xylose: $6.0 \pm 0.1 \%$ TS $)$ and higher COD contents than that of cattle manure $(L$. digitata: $1.2 \mathrm{~g} \mathrm{COD} / \mathrm{g} \mathrm{VS}$, cattle manure: $1.0 \mathrm{~g}$ COD/g VS).

The results from the BMP assays showed that the degradation period for all the tested ratios lasted up to 17 days (Fig. 2). Especially, the mixtures with higher L. digitata contents required less time to achieve maximum methane potential indicating a faster conversion rate of substrates to methane. The methane production from BMP assays increased in a linear relationship $\left(\mathrm{R}^{2}=0.94, \mathrm{RMSE}=7.87\right)$ with the increase of $L$. digitata share in feedstock. Moreover, it was verified that the observed methane yield does not display significant variation from the calculated value based on a linearity assumption (maximum variation $=4.7 \%$ ). Therefore, it can be concluded that neither synergistic nor inhibitory effects occurred during the degradation of the two substrates. It should be noted that the highest methane yield was achieved during the mono-digestion of L. digitata (Fig. 1). However, mono-digestion of $L$. digitata could suffer a potential $\mathrm{pH}$ drop which is attributed to the rapid hydrolysis of the biomass. Since this macroalgal species does not contain hard lignocellulose compounds, it can be easily hydrolyzed leading to an increment of VFA concentration, which will in 
turn cause perturbation to the $\mathrm{pH}$ values due to limited buffer capacity in the system. Low $\mathrm{pH}$ in the first few days of BMP tests with mono-digestion L. digitata at $55^{\circ} \mathrm{C}$ inhibited the biogas process and prolonged the lag phase (9.3 days) (Membere and Sallis, 2018). Therefore, the issue of $\mathrm{pH}$ decline should be seriously considered, so as to enhance biogas production and obtain a stable process during degradation of $L$. digitata. In addition, macroalgae have high sodium contents as they are collected from marine environments and thus, they rapidly lead to irreversible inhibition of the AD microbiome (Tsapekos et al., 2019).

Moreover, L. digitata harvested in autumn usually has a high C/N ratio (range: approximately 25-70) (D'Este et al., 2017). Digestion of such substrates may not generate adequate buffer capacity corresponding to large amounts of VFAs produced during the fermentation process. Nevertheless, although digestion of substrates with a low $\mathrm{C} / \mathrm{N}$ ratio (below 10), such as cattle manure, could have high buffer capacity (Tsapekos et al., 2018), the potential risk of ammonia accumulation in the reactor and inhibition in AD process still exists (Hagos et al., 2017). Moreover, beach-cast seaweed usually has high salt contents, which may be accumulated in the reactor, thus inhibiting the AD process after long-term operation. Therefore, the addition of co-substrates is necessary to dilute the inhibitory compounds and balance the nutrient supply ensuring a stable digestion process (Ganesh Saratale et al., 2018). Compared with $L$. digitata, cattle manure contains a higher concentration of $\mathrm{Ca}^{2+}, \mathrm{Mg}^{2+}, \mathrm{K}^{+}$and a lower concentration of $\mathrm{Na}^{+}$(Table 1), which makes it a good candidate as co-substrate for $\mathrm{AD}$ of $L$. digitata. Thus, the influent ratio of L. digitata and cattle manure can offer $\mathrm{C} / \mathrm{N}$ ratio balance, nutrient supply, improved buffer capacity, diluted inhibitory compounds and ultimately higher biogas yield (Ganesh Saratale et al., 2018).

Hence, co-digestion strategy is recommended when macroalgae is used for bioenergy production. With respect to co-digestion, the highest methane yield was achieved using a mixing ratio of $L$. 
digitata to cattle manure at $80: 20$ on VS basis in the feedstock $(263 \pm 21 \mathrm{~mL} / \mathrm{g} \mathrm{VS})$. Therefore, this mixing ratio was selected to be tested during continuous reactor operation.

\subsection{Continuous co-digestion of $L$. digitata with cattle manure}

The CSTR operation can better simulate the full-scale biogas reactors operation, compared to the batch tests. In this case, a continuous experiment was conducted to further investigate the biogas production performance by co-digesting L. digitata with cattle manure. A mixing ratio of 80:20 on VS basis between $L$. digitata and cattle manure in the feedstock was adopted since it presented the highest methane productivity in the co-digestion BMP assays. As shown in Fig. 3A, the biogas and methane yield rapidly increased along with the decrease of VFAs concentration during the startup period of the experiment. The maximum bioenergy production was reached after 10 days of operation without facing any technical challenges. Stable reactor operation was recorded even after the second HRT.

At steady state conditions, the biogas production was $1.08 \pm 0.07 \mathrm{~L} / \mathrm{L} /$ day with a constant methane content of $56.72 \pm 2.04 \%$. The specific methane yield (SMY) of the CSTR was $290 \pm 19 \mathrm{~mL} / \mathrm{g} \mathrm{VS}$. Apparently, the result was higher than that in the BMP assays described in section 3.1. The main reason is that the feedstock has been changed between the two experimental sets. Even though the sampling source of cattle manure was the same, the biophysical properties still slightly changed after sieving treatment (Table 1 and Table 2). The BMP results represented $68.11 \%$ of TMP (396 mL $\mathrm{CH}_{4} / \mathrm{g}$ VS) based on COD concentrations. The digestion efficiency (SMY/TMP) of the CSTR reached $66.1 \%$. Thus, the SMY of the continuous experiment could reach $97 \%$ of the BMP results, which highlights the high efficiency of the investigated system, as the SMY of a continuous reactor usually ranged between 70-90\% of the BMP value (Tsapekos et al., 2018). The HRT of the continuously operating reactor was set to 15 days that was longer than the time required for 
achieving the maximum methane production (around seven days, Fig. 2) in BMP tests. A similar finding has been reported during co-digestion of L. digitata and dairy slurry, presenting high biomethane efficiency (SMY/BMP) with a range of $95 \%$ to $113 \%$ (Tabassum et al., 2016).

Regarding other operational parameters, $\mathrm{pH}$ was stable $(7.18 \pm 0.12)$ at steady state conditions (Fig. 3B) and maintained within the favorable range of $\mathrm{AD}$ process (i.e. 6.8-7.4) (Kougias and Angelidaki, 2018). No accumulation of VFAs concentration was recorded during the experiment. A slight peak in acetate concentration (628 mg HAc/L) was recorded during the fifth HRT (E-supplement data), which was most probably due to a temporary temperature drop (Westerholm et al., 2018).

Regarding the individual VFAs, acetic, propionic and butyric acids were the dominant intermediates and maintained at a very low concentration levels during the whole experimental period (Fig. 3C). Thereby, a well-performing AD process with co-digestion of L. digitata and cattle manure can be proved. The accumulation of propionic acid (up to $602 \mathrm{mg} / \mathrm{L}$ ) was the main reason for the recorded peak of total VFAs during the fifth HRT. In the AD process, propionic acid is mainly produced through hydrolysis and fermentation of proteins or carbohydrates and through oxidation of long chain fatty acids (McCarty and Smith, 1986). In addition, accumulation of propionic acid has been considered a status indicator of the AD process, as its concentration is typically increased at non-stable operation (Lee et al., 2015). The propionic acid accumulation appeared to be dominant in the anaerobic treatment of the complex substrates (Lee et al., 2015). A shift of the dominant VFAs from acetic to propionic has also been observed in the condition of the VS share rise of L. digitata from $15 \%$ to $24 \%$ in thermophilic co-digestion with cattle manure (Sarker et al., 2014). In the present study, the concentration of propionic acid was rapidly increased (even at low levels) due a temporary system failure which caused a sudden drop in the operational temperature. Nonetheless, the subsequent recovery of the VFAs demonstrated that the system is able to tolerate disturbances to some extent. 
Marine algae are usually associated with high concentrations of sulfate and protein (Haghighatafshar, 2012), which can generate high concentrations of $\mathrm{H}_{2} \mathrm{~S}$ in the output biogas. In an anaerobic digester, $\mathrm{H}_{2} \mathrm{~S}$ can be produced by sulfate reduction, anaerobic reduction of sulfur-containing amino acids in undigested proteins and sulfur compounds oxidization (Huber et al., 2016; Peu et al., 2011). The presence of $\mathrm{H}_{2} \mathrm{~S}$ can be toxic to methanogens and sulfate-reducing bacteria since the unionized $\mathrm{H}_{2} \mathrm{~S}$ in biogas slurry is able to permeate the cell membrane (Haghighatafshar, 2012). The measured $\mathrm{H}_{2} \mathrm{~S}$ concentrations during the second and third HRT period were $0.21 \%$ and $0.25 \%$, respectively, having an average value of $0.24 \pm 0.02 \%$ during the operation period of days 86-93. Its concentration is below the median inhibition value for methanogenic activity (3.3-13\% at pH 7-8) (Haghighatafshar, 2012; Peu et al., 2011). However, such levels of $\mathrm{H}_{2} \mathrm{~S}$ content in the biogas is problematic for its further utilization in combined heat and power units. It is well known that $\mathrm{H}_{2} \mathrm{~S}$ is corrosive to the piping installations, and its concentration in biogas is recommended to be lower than $0.0065-0.03 \%$ by most manufacturers (Peu et al., 2012). Moreover, the $\mathrm{H}_{2} \mathrm{~S}$ content (around $0.25 \%$ ) measured in the current study was found to be lower compared to that of a previous work using Ulva sp. seaweed as a co-substrate for biogas production (i.e. 3.5\% concentration) (Peu et al., 2011). Obviously, L. digitata has a lower $\mathrm{H}_{2} \mathrm{~S}$ production, which reduces the extent of post-treatment of biogas.

Moreover, the TAN content of the effluent declined to $211 \pm 5 \mathrm{mg} \mathrm{NH}_{4}{ }^{+} \mathrm{N} / \mathrm{L}$ after long-term operation, which was in agreement with the result of a previous study (Tabassum et al., 2016). The main reason for the low effluent TAN concentration is attributed to the poor content of nitrogen in the feedstock. The TKN and TAN concentrations in the feeding substrates were $632.7 \pm 18.4$ and $245.9 \pm 5.1 \mathrm{mg} / \mathrm{L}$, respectively. These concentrations are far below the inhibitive threshold values for the AD process (Rajagopal et al., 2013). 
In accordance with the present study, Guneratnam et al. (2017) used L. digitata of similar anaerobic biodegradability (i.e. $308 \pm 24$ and $305 \pm 9 \mathrm{~mL} / \mathrm{g}$ VS in the present and previous work, respectively). However, in the cited study more than 95 days were needed to acclimatize the microbial community and achieve stable $\mathrm{pH}, \mathrm{VFA}$ and methane production. In contrast, in the present study the process performance was highly efficient even from the first days of adding L. digitata in the feedstock. The acclimation period is essential to ensure high expression of important enzymes (e.g., alginate lyase) which will disintegrate the macroalgal biomass. Another explanation for the better process performance is attributed to the operating temperature. It is well known that thermophilic biogas reactors withstand higher organic loads and present improved energy balance compared to digesters that operate at mesophilic conditions (Kougias and Angelidaki, 2018). Thus, thermophilic fermentation might be preferable for $\mathrm{AD}$ of macroalgae to gain high methane production and biomethane efficiency, as well as short HRT (Membere and Sallis, 2018; Vanegas and Bartlett, 2013).

\subsection{Simulation results}

Following the methodology described earlier and using the available experimental information, step (1) of the simulation procedure was applied on the outcomes of the batch experiment. After inserting the inoculum composition to the BioModel and setting the digestion temperature and duration according to the experimental conditions, simulations were initially run for the blank batches. Results of these simulations were used to calibrate the inoculum composition (insoluble, soluble and inert carbohydrate and protein fractions) used in the model, as well as to find the hydrolysis constant $k_{0}$ that provided the best simulation fit with the measured data. The former was necessary, given the inoculum carbohydrate and protein fractions were experimentally defined as total values, without distribution according to their solubility. Meanwhile, as $k_{0}$ signifies the rate at 
which the first-order hydrolysis of complex matter took place in the simulated batches, it was assumed to be the rate-limiting factor with a direct effect on the profile of the cumulative gas production. The calibrated inoculum fractions and the $k_{0}$ value were subsequently validated by simulating the control batches with the model.

Subsequently, cattle manure and L. digitata compositions were added to the BioModel and the treated batches with different mixing ratios were simulated. The compositions of manure and macroalgae were defined according to the analytical measurements, while the $k_{0}$ (i.e. $1.50,1.28$, $1.06,0.84,0.62,0.40)$ was calculated for the individual simulations of the different mix ratios of $L$. digitata and cattle manure in the feedstock (i.e. 0:100, 20:80, 40:60, 60:40, 80:20, 100:0). By doing so, the difference in degradation rate between the manure and macroalgae could be taken into account. On this context, more aquatic biomass in the substrate mixture results in lower refractory lignocellulose concentrations (Hanssen et al., 1987) and thus, faster conversion. It can be seen that the simulation results (Fig. 3) agree well with the experimental data, both during the initial lag and the main gas generation periods.

In step (2) of the simulation procedure, the model in turn was applied to the simulation of the continuous co-digestion experiment, where data from the first three HRTs of the experiment were used to evaluate the performance of the model. The value of $k_{0}\left(1.28 \mathrm{~d}^{-1}\right)$ was defined based on the results of step (1), considering the hydrolysis constant used for the simulation of the batches with $80 \%$ L. digitata and $20 \%$ cattle manure. A visualization of the results can be seen in Fig. 3, where calibration indicates the initial period of three HRTs. Focusing on the gas (Fig. 3A), pH (Fig. 3B) and VFAs (Fig. 3C) plots, it appears that the fits between simulated curves and measured data points are of high accuracy, suggesting that the model captured the dynamics of the continuous experiment well. To validate the reliability of the model, step (3) of the simulation procedure was 
carried out, in which the simulation period was extended to the full length of the experiment and measurement data from the remainder of the experiment were compared with the simulation output. This comparison is depicted in validation (the second period) of Fig. 3 and suggests that the model simulation was indeed reliable for the whole operation of the continuous reactor. The only clear exception for close simulation-experiment fits was the propionic acid concentration between days 71 and 77. However, this effect was deemed negligible from the perspective of the experiment. Although also visible, the slight increase in the simulated VFAs concentrations, and thus, deviation from experimental data points during validation was shown. Adaptive microbial behavior, which over time could lower VFAs concentrations below simulated levels is the result of complex cell-specific processes, the inclusion of which in dynamic models is likely to form part of subsequent studies.

Based on the comparison of all simulations with their experimental counterparts, it can be recognized that the BioModel was successfully applied to the co-digestion simulation of $L$. digitata and cattle manure. Results of the simulated continuous operation showed that the model is consistent in its provision of reliable process information, and it can capture process dynamics to an extent that might justify its use in larger scale experiments as well. Furthermore, simulations of the batch operations without any structural modifications to the model proved the robustness of the BioModel, and may offer a useful extension to the functionalities of this practical tool.

\section{Conclusions}

The methane production of manure-based biogas reactors can be enhanced via the addition of $L$. digitata in the feedstock mixture. Specifically, co-digestion of L. digitata with cattle manure was associated with stable methane production equal to $290 \mathrm{~mL} / \mathrm{g}$ VS at long-term operation. The 
present findings can be exploited for sustainable bioenergy conversion and waste treatment for seaweed and manure. Moreover, the successful simulation of both batch and continuous experiments provided mutual proof verifications for the reliability of experimental measurements and the robustness of the model. Thus, the BioModel could be used in larger scale experiments as a practical, multi-purpose simulation tool.

\section{Acknowledgments}

The authors thank Hector Garcia for technical assistance. This work was supported by ForskEL Project 12197 "Improving Synergy and Robustness of the Manure Co-digestion Process". We likewise greatly appreciate the support of the China Scholarship Council (CSC). 


\section{References}

1. Adams, J.M.M., Toop, T.A., Donnison, I.S., Gallagher, J.A., 2011. Seasonal variation in Laminaria digitata and its impact on biochemical conversion routes to biofuels. Bioresource Technology, 102, 9976-9984.

2. Allen, E., Wall, D.M., Herrmann, C., Xia, A., Murphy, J.D., 2015. What is the gross energy yield of third generation gaseous biofuel sourced from seaweed? Energy, 81, 352-360.

3. Angelidaki, I., Alves, M., Bolzonella, D., Borzacconi, L., Campos, J.L., Guwy, A.J., Kalyuzhnyi, S., Jenicek, P., van Lier, J.B., 2009. Defining the biomethane potential (BMP) of solid organic wastes and energy crops: a proposed protocol for batch assays. Water Science And Technology, 59, 927-934.

4. Angelidaki, I., Ellegaard, L., Ahring, B.K., 1992. Compact automated displacement gas metering system for measurement of low gas rates from laboratory fermentors. Biotechnology And Bioengineering, 39, 351-353.

5. Angelidaki, I., Ellegaard, L., Ahring, B.K., 1993. A mathematical model for dynamic simulation of anaerobic digestion of complex substrates: focusing on ammonia inhibition. Biotechnology And Bioengineering, 42, 159-166.

6. Angelidaki, I., Ellegaard, L., Ahring, B.K., 1999. A comprehensive model of anaerobic bioconversion of complex substrates to biogas. Biotechnology And Bioengineering, 63, 363-372.

7. APHA, 2005. Standard methods for the examination of water and wastewater. American Public Health Association, Washington, DC, USA.

8. Batstone, D.J., Puyol, D., Flores-Alsina, X., Rodríguez, J., 2015. Mathematical modelling of anaerobic digestion processes: applications and future needs. Reviews in Environmental Science and Bio/Technology, 14, 595-613.

9. Behera, S., Singh, R., Arora, R., Sharma, N.K., Shukla, M., Kumar, S., 2015. Scope of algae as third generation biofuels. Frontiers in bioengineering and biotechnology, 2, 90.

10. Bentsen, N.S., Møller, I.M., 2017. Solar energy conserved in biomass: Sustainable bioenergy use and reduction of land use change. Renewable and Sustainable Energy Reviews, 71, 954-958.

11. D'Este, M., Alvarado-Morales, M., Ciofalo, A., Angelidaki, I., 2017. Macroalgae Laminaria digitata and Saccharina latissima as Potential Biomasses for Biogas and Total Phenolics Production: Focusing on Seasonal and Spatial Variations of the Algae. Energy \& Fuels, 31, 
7166-7175.

12. Donoso-Bravo, A., Mailier, J., Martin, C., Rodríguez, J., Aceves-Lara, C.A., Wouwer, A.V., 2011. Model selection, identification and validation in anaerobic digestion: a review. Water Research, 45, 5347-5364.

13. Edward, M., Edwards, S., Egwu, U., Sallis, P., 2015. Bio-methane potential test (BMP) using inert gas sampling bags with macroalgae feedstock. Biomass and Bioenergy, 83, 516-524.

14. Ellabban, O., Abu-Rub, H., Blaabjerg, F., 2014. Renewable energy resources: Current status, future prospects and their enabling technology. Renewable and Sustainable Energy Reviews, $39,748-764$.

15. European-Council, 2014. 2030 climate and energy policy framework, conclusions, EUCO 169/14. European Council.

16. Ganesh Saratale, R., Kumar, G., Banu, R., Xia, A., Periyasamy, S., Dattatraya Saratale, G., 2018. A critical review on anaerobic digestion of microalgae and macroalgae and co-digestion of biomass for enhanced methane generation. Bioresource Technology, 262, 319-332.

17. Guneratnam, A.J., Xia, A., Murphy, J.D., 2017. Comparative study of single- and two-stage fermentation of the brown seaweed Laminaria digitata. Energy Conversion And Management, $148,405-412$.

18. Haghighatafshar, S., 2012. Management of hydrogen sulfide in anaerobic digestion of enzyme pretreated marine macro-algae. Lund University.

19. Hagos, K., Zong, J., Li, D., Liu, C., Lu, X., 2017. Anaerobic co-digestion process for biogas production: Progress, challenges and perspectives. Renewable and Sustainable Energy Reviews, $76,1485-1496$.

20. Hanssen, J.F., Indergaard, M., Østgaard, K., Bævre, O.A., Pedersen, T.A., Jensen, A., 1987. Anaerobic digestion of Laminaria spp. and Ascophyllum nodosum and application of end products. Biomass, 14, 1-13.

21. Huber, B., Herzog, B., Drewes, J.E., Koch, K., Müller, E., 2016. Characterization of sulfur oxidizing bacteria related to biogenic sulfuric acid corrosion in sludge digesters. $B M C$ microbiology, 16, 153.

22. Khoshnevisan, B., Tsapekos, P., Alvarado-Morales, M., Angelidaki, I., 2018. Process performance and modelling of anaerobic digestion using source-sorted organic household waste. Bioresource Technology, 247, 486-495.

23. Kougias, P.G., Angelidaki, I., 2018. Biogas and its opportunities-A review. Frontiers of 


\section{Environmental Science \& Engineering, 12.}

24. Kovalovszki, A., Alvarado-Morales, M., Fotidis, I.A., Angelidaki, I., 2017. A systematic methodology to extend the applicability of a bioconversion model for the simulation of various co-digestion scenarios. Bioresource Technology, 235, 157-166.

25. Kythreotou, N., Florides, G., Tassou, S.A., 2014. A review of simple to scientific models for anaerobic digestion. Renewable Energy, 71, 701-714.

26. Lee, D., Lee, S., Bae, J., Kang, J., Kim, K., Rhee, S., Park, J., Cho, J., Chung, J., Seo, D., 2015. Effect of volatile fatty acid concentration on anaerobic degradation rate from field anaerobic digestion facilities treating food waste leachate in South Korea. Journal of Chemistry, 2015.

27. Lovato, G., Alvarado-Morales, M., Kovalovszki, A., Peprah, M., Kougias, P.G., Rodrigues, J.A.D., Angelidaki, I., 2017. In-situ biogas upgrading process: Modeling and simulations aspects. Bioresource Technology, 245, 332-341.

28. McCarty, P.L., Smith, D.P., 1986. Anaerobic wastewater treatment. Environmental Science \& Technology, 20, 1200-1206.

29. Membere, E., Sallis, P., 2018. Effect of temperature on kinetics of biogas production from macroalgae. Bioresource Technology, 263, 410-417.

30. Mohr, A., Raman, S., 2013. Lessons from first generation biofuels and implications for the sustainability appraisal of second generation biofuels. Energy Policy, 63, 114-122.

31. Montingelli, M.E., Tedesco, S., Olabi, A.G., 2015. Biogas production from algal biomass: A review. Renewable and Sustainable Energy Reviews, 43, 961-972.

32. Naik, S.N., Goud, V.V., Rout, P.K., Dalai, A.K., 2010. Production of first and second generation biofuels: A comprehensive review. Renewable and Sustainable Energy Reviews, 14, 578-597.

33. Nasir, I.M., Ghazi, T.I.M., Omar, R., 2012. Anaerobic digestion technology in livestock manure treatment for biogas production: a review. Engineering in Life Sciences, 12, 258-269.

34. Nielsen, H.B., Heiske, S., 2011. Anaerobic digestion of macroalgae: methane potentials, pre-treatment, inhibition and co-digestion. Water Science And Technology, 64, 1723-1729.

35. Peu, P., Picard, S., Diara, A., Girault, R., Béline, F., Bridoux, G., Dabert, P., 2012. Prediction of hydrogen sulphide production during anaerobic digestion of organic substrates. Bioresource Technology, 121, 419-424.

36. Peu, P., Sassi, J., Girault, R., Picard, S., Saint-Cast, P., Béline, F., Dabert, P., 2011. Sulphur fate and anaerobic biodegradation potential during co-digestion of seaweed biomass (Ulva sp.) with 
pig slurry. Bioresource Technology, 102, 10794-10802.

37. Rajagopal, R., Massé, D.I., Singh, G., 2013. A critical review on inhibition of anaerobic digestion process by excess ammonia. Bioresource Technology, 143, 632-641.

38. Sarker, S., Møller, H.B., Bruhn, A., 2014. Influence of variable feeding on mesophilic and thermophilic co-digestion of Laminaria digitata and cattle manure. Energy Conversion And Management, 87, 513-520.

39. Scarlat, N., Dallemand, J., Monforti-Ferrario, F., Banja, M., Motola, V., 2015. Renewable energy policy framework and bioenergy contribution in the European Union-An overview from National Renewable Energy Action Plans and Progress Reports. Renewable and Sustainable Energy Reviews, 51, 969-985.

40. Seghetta, M., Romeo, D., D'Este, M., Alvarado-Morales, M., Angelidaki, I., Bastianoni, S., Thomsen, M., 2017. Seaweed as innovative feedstock for energy and feed-Evaluating the impacts through a Life Cycle Assessment. Journal of Cleaner Production, 150, 1-15.

41. Smetacek, V., Zingone, A., 2013. Green and golden seaweed tides on the rise. Nature, 504, 84-88.

42. Tabassum, M.R., Wall, D.M., Murphy, J.D., 2016. Biogas production generated through continuous digestion of natural and cultivated seaweeds with dairy slurry. Bioresource Technology, 219, 228-238.

43. Tedesco, S., Daniels, S., 2018. Optimisation of biogas generation from brown seaweed residues: Compositional and geographical parameters affecting the viability of a biorefinery concept. Applied Energy, 228, 712-723.

44. Tsapekos, P., Alvarado-Morales, M., Kougias, P.G., Konstantopoulos, K., Angelidaki, I., 2019. Co-digestion of municipal waste biopulp with marine macroalgae focusing on sodium inhibition. Energy Conversion And Management, 180, 931-937.

45. Tsapekos, P., Kougias, P.G., Alvarado-Morales, M., Kovalovszki, A., Corbière, M., Angelidaki, I., 2018. Energy recovery from wastewater microalgae through anaerobic digestion process: Methane potential, continuous reactor operation and modelling aspects. Biochemical Engineering Journal, 139, 1-7.

46. Tsapekos, P., Kougias, P.G., Kuthiala, S., Angelidaki, I., 2018. Co-digestion and model simulations of source separated municipal organic waste with cattle manure under batch and continuously stirred tank reactors. Energy Conversion And Management, 159, 1-6.

47. Vanegas, C., Bartlett, J., 2013. Anaerobic Digestion of Laminaria digitata: The Effect of 
Temperature on Biogas Production and Composition. Waste and Biomass Valorization, 4, 509-515.

48. Westerholm, M., Isaksson, S., Lindsjö, O.K., Schnürer, A., 2018. Microbial community adaptability to altered temperature conditions determines the potential for process optimisation in biogas production. Applied Energy, 226, 838-848. 


\section{Figure Captions}

Figure 1. Methane yields of mono- and co-digestion of Laminaria digitata and cattle manure.

Figure 2. Cumulative $\mathrm{CH}_{4}$ production as a function of time in batch assays and their simulations with BioModel

Figure 3. Experimental data and simulations of (A) biogas and methane production rates, (B) $\mathrm{pH}$ variation and (C) acetic and propionic acid concentrations from the continuous co-digestion of Laminaria digitata with cattle manure 
Table 1. Characteristics of inoculum, seaweeds, and cattle manure for the batch experiment.

\begin{tabular}{llll}
\hline Characteristics & Inoculum & Cattle manure & Laminaria digitata \\
\hline $\mathrm{pH}$ & $7.65 \pm 0.05$ & $7.24 \pm 0.05$ & 1 \\
$\mathrm{TS}, \mathrm{g} / \mathrm{kg}$ & $10.57 \pm 0.32$ & $43.75 \pm 1.29$ & $960.80 \pm 5.7$ \\
$\mathrm{VS}, \mathrm{g} / \mathrm{kg}$ & $6.40 \pm 0.51$ & $34.40 \pm 0.99$ & $714.60 \pm 6.8$ \\
$\mathrm{COD}, \mathrm{g} / \mathrm{kg}$ & $7.57 \pm 0.28$ & $32.6 \pm 0.41$ & $838.42 \pm 5.23$ \\
$\mathrm{TKN}, \mathrm{g} / \mathrm{kg}$ & $1.03 \pm 0.02$ & $1.66 \pm 0.01$ & $7.47 \pm 0.45$ \\
$\mathrm{NH} 4+, \mathrm{g} / \mathrm{kg}$ & $0.77 \pm 0.02$ & $1.11 \pm 0.04$ & $0.97 \pm 0.97$ \\
Proteins, g/kg & $6.42 \pm 0.12$ & $10.37 \pm 0.07$ & $36.77 \pm 2.19$ \\
TVFAs, g/L & $0.21 \pm 0.02$ & $6.73 \pm 0.30$ & 1 \\
Acetate, g/L & $0.16 \pm 0.02$ & $4.49 \pm 0.29$ & 1 \\
Propionate, g/L & $0.01 \pm 0.00$ & $1.19 \pm 0.08$ & 1 \\
Iso-butyrate, g/L & $<0.01$ & $0.16 \pm 0.00$ & 1 \\
Butyrate, g/L & $<0.01$ & $0.59 \pm 0.02$ & 1 \\
Iso-valerate, g/L & $0.04 \pm 0.00$ & $0.27 \pm 0.08$ & 1 \\
Valerate, g/L & $<0.01$ & $0.05 \pm 0.00$ & $8.15 \pm 0.10$ \\
Calcium, g/kg TS & 1 & $23.60 \pm 0.48$ & $4.70 \pm 0.10$ \\
Magnesium, g/kg TS & 1 & $9.52 \pm 0.15$ & $12.84 \pm 0.44$ \\
Potassium, g/kg TS & 1 & $18.94 \pm 0.70$ & $18.92 \pm 0.76$ \\
Sodium, g/kg TS & 1 & $7.38 \pm 0.26$ & $6.62 \pm 0.24$ \\
Sulphur, g/kg TS & 1 & 1 & \\
\hline
\end{tabular}

I: not measured 
Table 2. Characteristics of inoculum, seaweeds, and cattle manure for CSTR experiment.

\begin{tabular}{lllll}
\hline Characteristics & Inoculum & Cattle manure & Laminaria digitata & Mix-feed \\
\hline $\mathrm{pH}$ & $8.69 \pm 0.05$ & $7.05 \pm 0.05$ & 1 & $7.13 \pm 0.05$ \\
$\mathrm{TS}, \mathrm{g} / \mathrm{kg}$ & $28.32 \pm 0.12$ & $84.47 \pm 0.58$ & $944.37 \pm 0.83$ & $36.99 \pm 0.93$ \\
$\mathrm{VS}, \mathrm{g} / \mathrm{kg}$ & $18.19 \pm 0.06$ & $59.92 \pm 0.42$ & $795.09 \pm 7.50$ & $31.43 \pm 0.74$ \\
$\mathrm{COD}, \mathrm{g} / \mathrm{kg}$ & $33.58 \pm 1.59$ & $100.75 \pm 6.93$ & $914.67 \pm 1.43 \mathrm{~g} / \mathrm{Kg}$ & $39.5 \pm 1.46$ \\
$\mathrm{TKN}, \mathrm{g} / \mathrm{kg}$ & $3.34 \pm 0.04$ & $3.26 \pm 0.06$ & $7.06 \pm 0.14$ & $0.59 \pm 0.02$ \\
$\mathrm{NH} 4+, \mathrm{g} / \mathrm{kg}$ & $2.32 \pm 0.02$ & $1.73 \pm 0.04$ & $0.95 \pm 0.02$ & $0.24 \pm 0.00$ \\
Proteins, g/kg & $5.71 \pm 0.34$ & $8.53 \pm 0.56$ & $34.18 \pm 0.90$ & $1.98 \pm 0.11$ \\
$\mathrm{TVFAs}, \mathrm{g} / \mathrm{L}$ & $0.16 \pm 0.00$ & $3.60 \pm 0.02$ & 1 & $0.42 \pm 0.11$ \\
Acetate, g/L & $0.08 \pm 0.00$ & $3.08 \pm 0.01$ & 1 & $0.28 \pm 0.01$ \\
Propionate, g/L & $<0.01$ & $0.85 \pm 0.03$ & 1 & $0.07 \pm 0.00$ \\
Iso-butyrate, g/L & $<0.01$ & $0.42 \pm 0.01$ & 1 & $<0.01$ \\
Butyrate, g/L & $0.04 \pm 0.00$ & $0.14 \pm 0.00$ & 1 & $0.02 \pm 0.02$ \\
Iso-valerate, g/L & $<0.01$ & $0.06 \pm 0.00$ & 1 & $0.01 \pm 0.00$ \\
Valerate, g/L & $0.03 \pm 0.00$ & $<0.01$ & 1 & $<0.01$ \\
\hline
\end{tabular}

I: not measured 


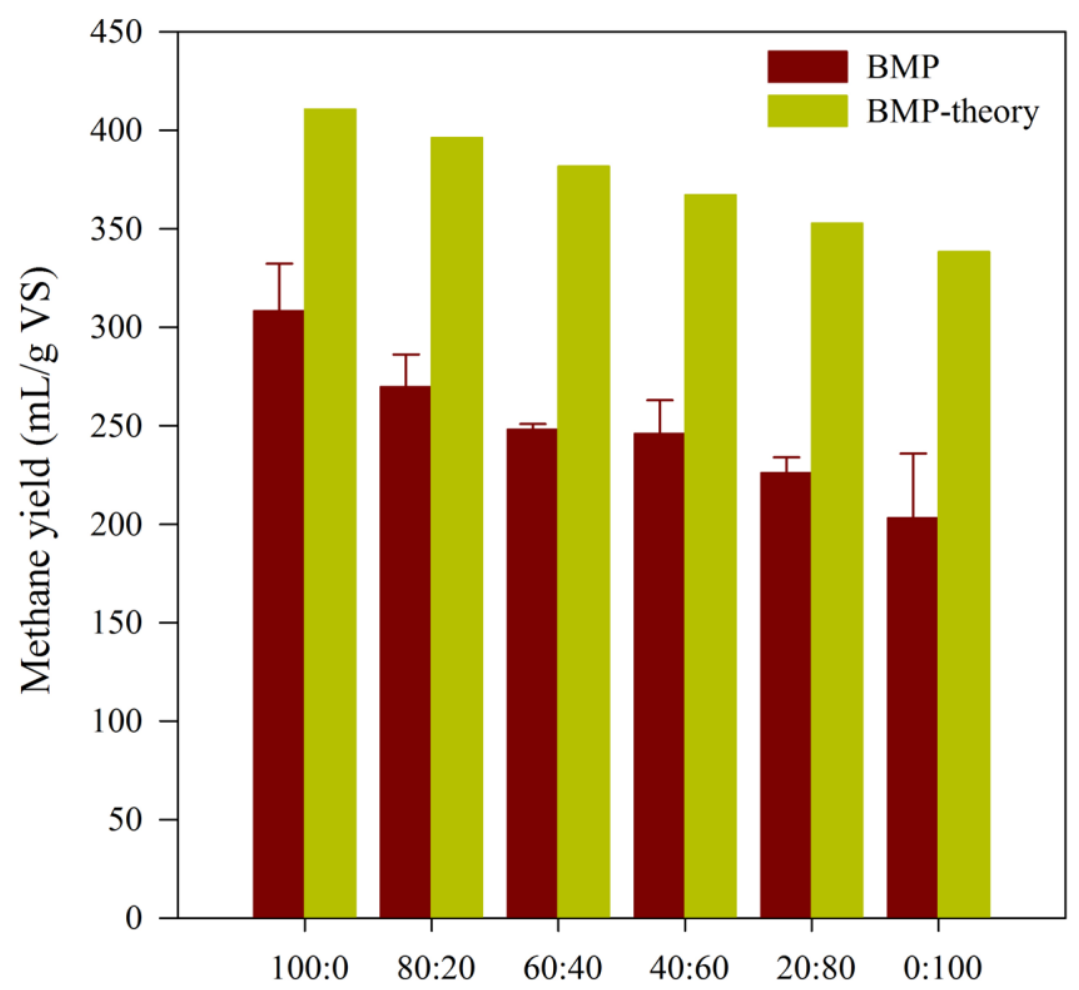

VS share, Laminaria digitata: Cattle manure 

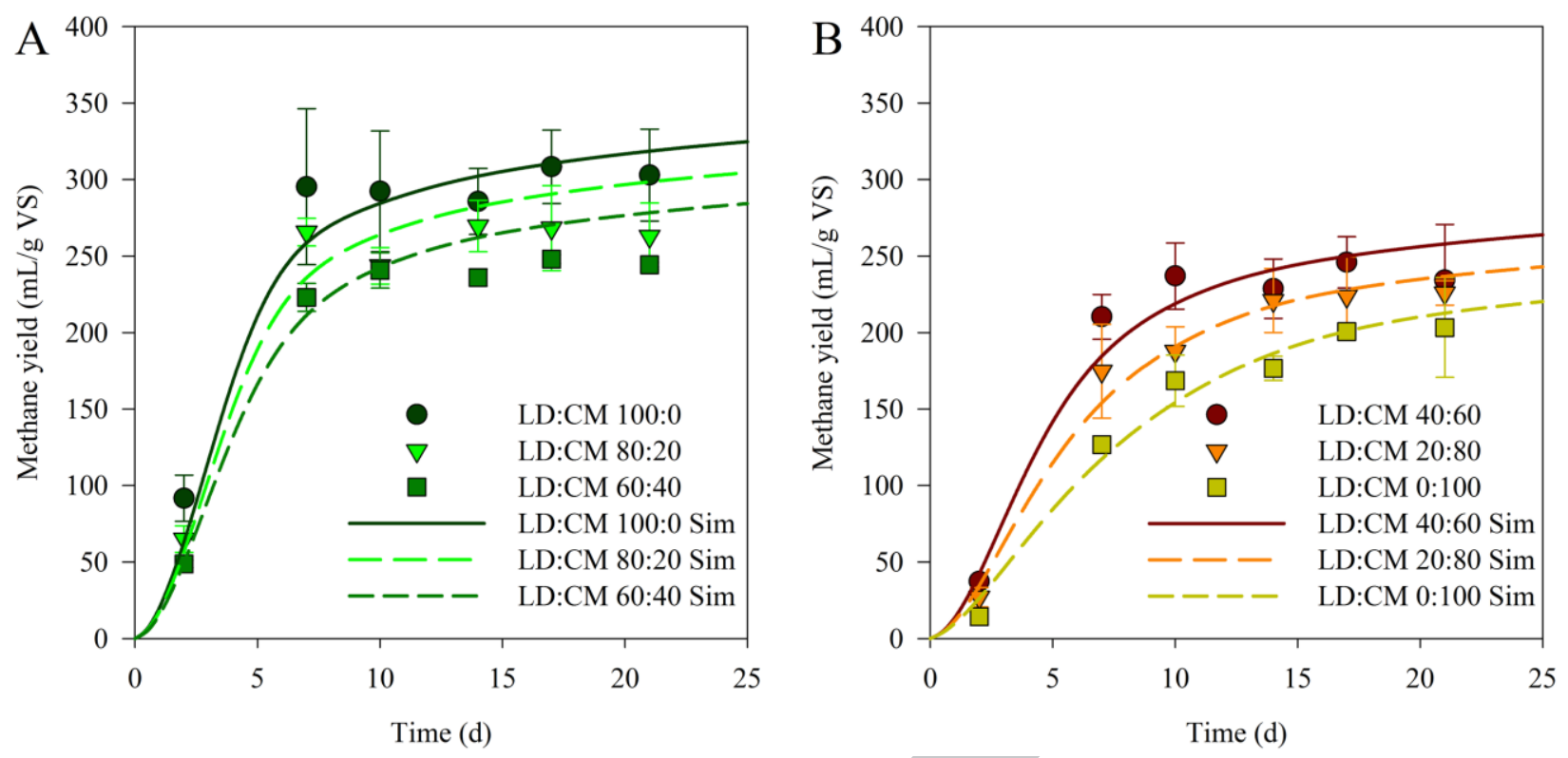

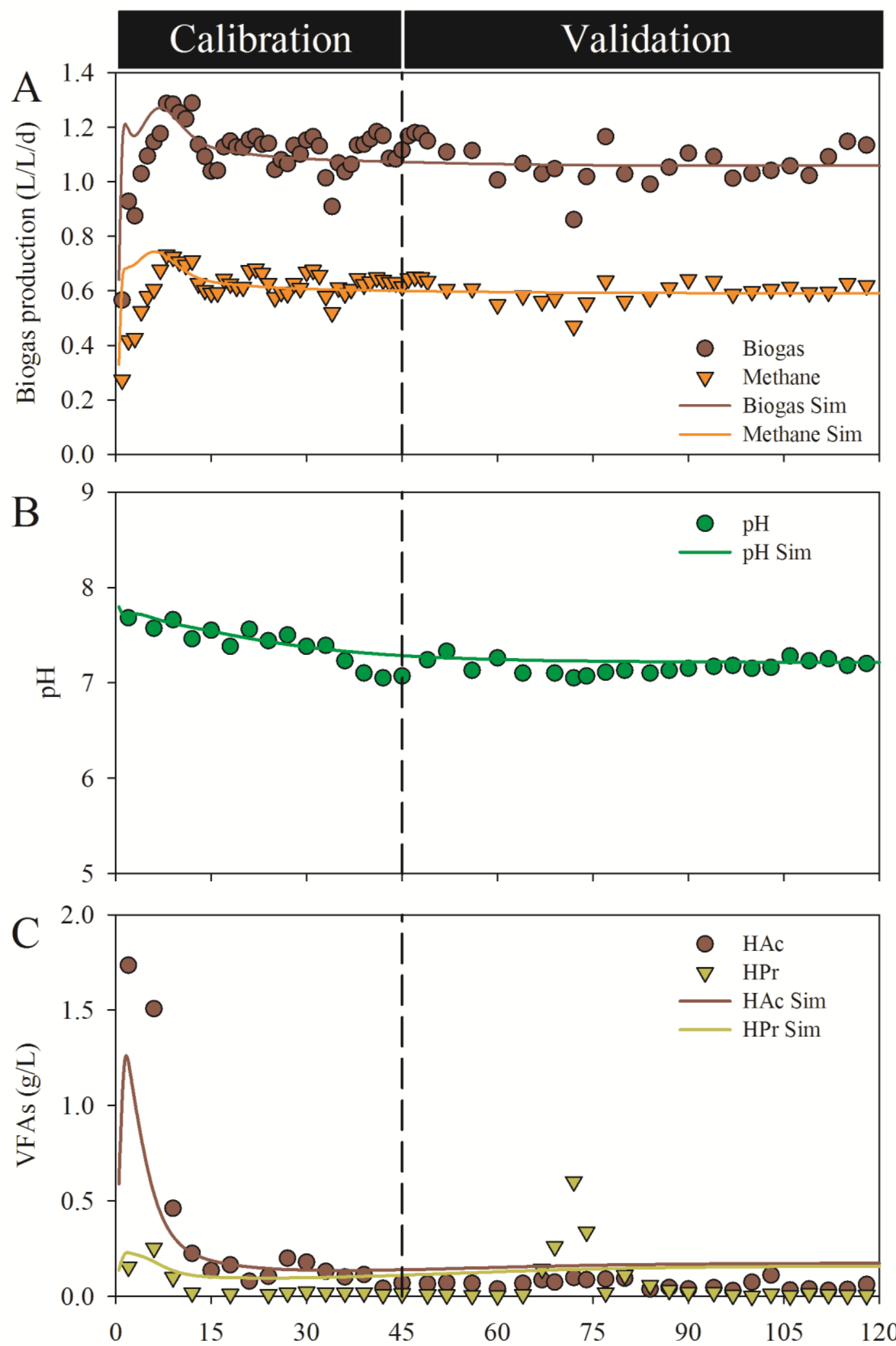

Time (d) 


\section{Highlights}

- Co-digestion of Laminaria digitata and cattle manure improved the bioenergy output

- Laminaria digitata enhanced biogas yield and cattle manure provided buffer capacity

- Results from batch and continuous reactor were confirmed by BioModel simulation

- BioModel could be used as a practical and multi-purpose simulation tool 